\begin{tabular}{|c|c|}
\hline \multicolumn{2}{|c|}{ Marine Biodiversity } \\
\hline \multicolumn{2}{|c|}{$\begin{array}{l}\text { Unusual behavior and habitat use of a male solitary dugong inhabiting coral reefs at } \\
\text { the Cocos (Keeling) Islands } \\
\text {--Manuscript Draft-- }\end{array}$} \\
\hline Manuscript Number: & MARB-D-14-00192R1 \\
\hline Full Title: & $\begin{array}{l}\text { Unusual behavior and habitat use of a male solitary dugong inhabiting coral reefs at } \\
\text { the Cocos (Keeling) Islands }\end{array}$ \\
\hline Article Type: & Oceanarium \\
\hline Corresponding Author: & $\begin{array}{l}\text { Jean-Paul Adrian Hobbs, Ph.D. } \\
\text { Curtin University } \\
\text { Perth, Western Australia AUSTRALIA }\end{array}$ \\
\hline \multicolumn{2}{|l|}{$\begin{array}{l}\text { Corresponding Author Secondary } \\
\text { Information: }\end{array}$} \\
\hline Corresponding Author's Institution: & Curtin University \\
\hline \multicolumn{2}{|l|}{$\begin{array}{l}\text { Corresponding Author's Secondary } \\
\text { Institution: }\end{array}$} \\
\hline First Author: & Jean-Paul Adrian Hobbs, Ph.D. \\
\hline \multicolumn{2}{|l|}{ First Author Secondary Information: } \\
\hline \multirow{2}{*}{ Order of Authors: } & Jean-Paul Adrian Hobbs, Ph.D. \\
\hline & Karen Willshaw \\
\hline \multicolumn{2}{|c|}{ Order of Authors Secondary Information: } \\
\hline \multicolumn{2}{|l|}{ Funding Information: } \\
\hline Abstract: & Oceanarium \\
\hline Response to Reviewers: & File uploaded \\
\hline
\end{tabular}




\section{Unusual behavior and habitat use of a male solitary dugong inhabiting coral reefs at the Cocos (Keeling) Islands}

Dugongs are distributed through the tropics and subtropics from east Africa to Vanuatu (Marsh et al. 2011). They prefer shallow $(<10 \mathrm{~m}$ ) protected inshore areas where their food source (seagrass) is abundant. The Cocos (Keeling) Islands $\left(12^{\circ} 12^{\prime} \mathrm{S}, 96^{\circ} 54^{\prime} \mathrm{E}\right)$ are an oceanic coral atoll in the Indian Ocean and not typical habitat of dugongs. In June 2002, a solitary male dugong ( $2 \mathrm{~m}$ in length) colonised the Cocos Islands having travelled more than $1000 \mathrm{~km}$ through oceanic waters greater than $5000 \mathrm{~m}$ deep (Hobbs et al. 2007). This remarkable colonisation event is well beyond the known geographic range of the species (Marsh et al. 2011). Here we describe the dugong's unusual behavior and habitat use based on our underwater observations from 2002 to 2014.

Dugongs tend not to interact with humans, however the Cocos dugong regularly approaches divers and snorkelers, coming within $0.5 \mathrm{~m}$ (Hobbs et al. 2007, Fig. 1a). These interactions are commonly 5 to 20 mins duration (Hobbs et al. 2007), but can last up to an hour. The dugong's unusual behavior includes approaching divers face-to-face, vertical orientation facing divers, circling divers, and using its forelimbs to spin around the anchor line (Fig. 1b). Human interactions have also been observed for a solitary dugong in Vanuatu (Adam, 1998). The Cocos dugong occasionally lies on its side motionless on the sand. Vocalisations of the dugong can be heard throughout the dive (Hobbs et al. 2007). The dugong chases large animals, including turtles, dolphins and manta rays, and is found with batfish and unicornfish (Fig. 1a,c). A lack of conspecifics may explain why the dugong interacts with humans and large marine fauna.

There are extensive seagrass beds within the shallows of the Cocos lagoon, however the dugong is usually seen on the outer reef dropoff, north of Direction Island (Hobbs et al. 2007). The water at this location is $20 \mathrm{~m}$ deep and drops rapidly to $5000 \mathrm{~m}$. The area is devoid of seagrass and consists of coral reef and sand (Hobbs et al. 2007). The dugong may use this habitat because it provides access to deeper water and a quick escape from predators (e.g. tiger sharks, Wirsing et al. 2007) or because it is a regular dive site and can interact with humans.

\section{References}

Adam S (1998) Dugong-human interactions. Sirenews 30:13-16

Hobbs J-PA, Frisch AJ, Hender J, Gilligan JJ (2007) Long-distance oceanic movement of a solitary dugong (Dugong dugon) to the Cocos (Keeling) Islands. Aquat Mamm 33:175-178

Marsh H, O’Shea TJ, Reynolds III JE (2011) Ecology and Conservation of the Sirenia: Dugongs and Manatees. Cambridge University Press, Cambridge

Wirsing AJ, Heithaus MR, Dill LM (2007) Living on the edge: dugongs prefer to forage in microhabitats that allow escape from rather than avoidance of predators. Anim Behav 74:93-101.

Jean-Paul A. Hobbs ${ }^{1 *}$ and Karen Willshaw ${ }^{2}$

1. Department of Environment and Agriculture, Curtin University, Perth, WA 6845, Australia

2. PO Box 1015, Cocos (Keeling) Islands, WA 6799, Australia

* e-mail: jp.hobbs@curtin.edu.au

\section{Figure legend}

Fig. 1 The Cocos dugong interacting with a) batfish and divers, b) anchor line, and c) manta ray. Photos: K. Willshaw. 
Figure
Click here to download Figure: Hobbs and Willshaw Fig1.tif

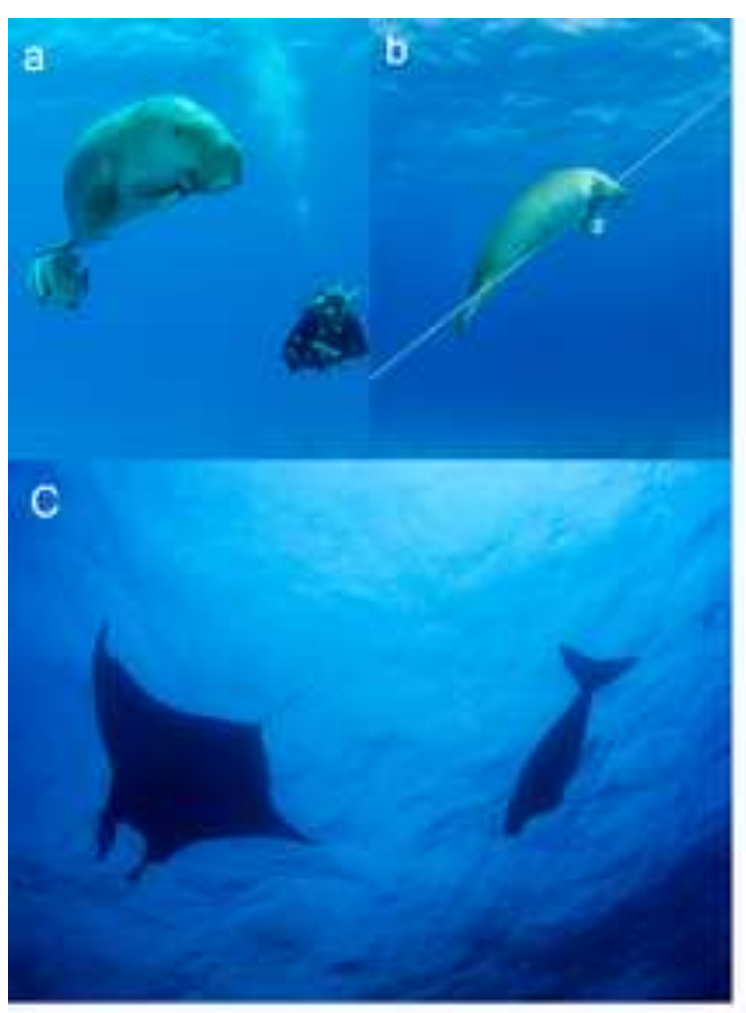

